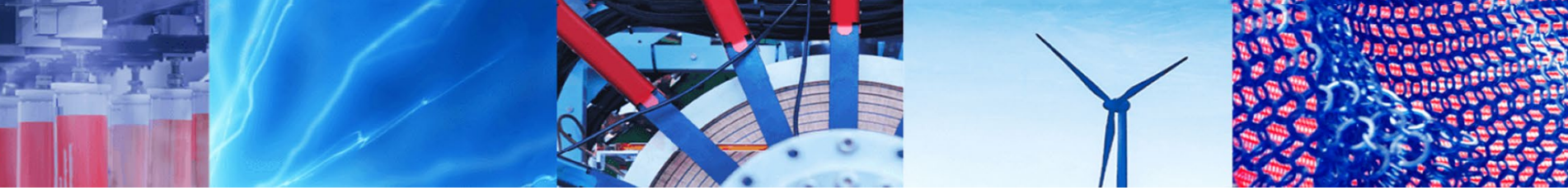

Research Article

\title{
Textural properties of chapatti from different wheat varieties flour
}

\author{
Shahid Yousaf ${ }^{1} \cdot$ Saqib Arif ${ }^{2} \cdot{\text { Qurrat UI Ain } \text { Akbar }^{2} \cdot \text { Hafiza Mehwish Iqbal }^{2} \cdot \text { Salman Khurshid }}^{2}$
}

Received: 21 January 2020 / Accepted: 14 March 2020 / Published online: 19 March 2020

C) Springer Nature Switzerland AG 2020

\begin{abstract}
This study was aiming to evaluate wheat flour parameters related to suitability for chapatti making, milled from Pakistani wheat varieties. Wholemeal flours (protein $=12.5-10.2 \%$; wet gluten $=21.0-26.0 \%$ and gluten index $=22-99$ ) of thirteen Pakistani wheat varieties grown in Pakistan varied in physicochemical and rheological characteristics, all varieties were suitable for chapatti making but Punjab-11, Galacy-13 and commercial wholemeal flour (CWMF) as a benchmark were found to be excellent for intended purpose. Moderate stickiness, sheeting ability and contraction after sheeting of dough was evaluated in Punjab-11, Galaxy-13 and CWMF, made dough easy to handle. Texture of chapatti was estimated by determining the softness through Instron Universal Testing Machine. Score by panel indicated that wholemeal flour of wheat varieties utilized for chapatti making were good to excellent in sensory attributes. Correlations were determined between some sensory and quality parameters of chapatti.
\end{abstract}

Keywords Wheat $\cdot$ Varieties $\cdot$ Sensory $\cdot$ Chapatti $\cdot$ Softness

\section{Introduction}

Chapatti (flat bread) made from wheat (Triticum aestivum L.) is consumed in South-Asia and Middle East, whole meal flour is preferred for intended purpose [1]. In Pakistan 90\% of wheat is consumed in form of chapatti and remaining for preparation of wheat based products [2]. Chapatti is made up of two portions, little crumb to large crust and consumed fresh just after baking [3]. Chapatti is a staple food to Indo-Pak and African region provides protein and calories on consumption [4].

Milling of wheat by different tampering times and clearance within rolls had been reflected significant impact on properties of flour [5]. Wheat flour quality is reflected by relationship of different parameters, single component is inadequate to evaluate the quality, investigation of several aspects are necessary to evaluate rheological properties and organoleptic characteristics of dough and chapatti respectively [6].
Quality attributes of chapatti are pliability, puffing, textural softness, and light creamy to brownish colour, chewiness and wheat like aroma at baking [1]. Ideal colour of chapatti was creamy with brownish spots at baking and puffed into two separate layers. The quality of end product is affected by class of wheat and influence of different constituents and their interaction [7]. Quality and quantity of protein, gluten content in wheat flour, and water absorption of whole meal flour influence the sensory evaluation of chapatti [8].

Quality characteristics of wheat for intended purpose can be optimized when physicochemical properties affecting technological attributes are identified. Chapatti is prepared from all Triticum aestivum (wheat) cultivars; variation in quality of chapatti was recorded made from different wheat cultivars. Chapatti is being prepared at home scale and consumed throughout the Asian region; therefore it is need to enhance processing potential and quality of this product by research either at milling end or screening of

$\triangle$ Shahid Yousaf, shahidyousaf160@yahoo.com; Saqib Arif, saqiawan@yahoo.com; Hafiza Mehwish lqbal, mehwishiqbal166@gmail.com; mehwishiqbal56@yahoo.com; Salman Khurshid, salmankhurshid67@gmail.com | ${ }^{1}$ Food Science Research Institute, NARC/PARC-Islamabad, Park Road, Islamabad, Pakistan. ${ }^{2}$ Food Quality \& Safety Research Institute, SARC/PARC-Karachi, Karachi, Pakistan. 
most suitable wheat varieties. This study was conducted to determine quality of chapatti from Pakistani wheat varieties flour by evaluating relationship of physicochemical, rheological and sensory attributes.

\section{Materials and methods}

Thirteen Pakistani wheat varieties (viz. Faisalabad-08, Chakwal-50, Aas-11, Punjab-11, NARC-11, Galaxy-13, Ujjala-16, Zincol-16, NIFA-Lalma, Pisabak-13, Shakkar-13, NIA-Amber and TD-1) were provided by International Maize and Wheat Improvement Centre (CIMMYT) Pakistan and wheat for commercial whole meal flour (CWMF) collected from Matiari Flour Mill Karachi. Each wheat sample was thoroughly mixed and subdivided into working samples using a precision electronic divider. Thereafter samples were cleaned manually using appropriate sieves to separate dust and smaller particles, and hand picking larger foreign material.

Cleaned, washed and dried wheat was conditioned to $14 \mathrm{~mL} / 100 \mathrm{~g}$ moisture content for $24 \mathrm{~h}$ [9]. Tempering was done by mixing $3 \mathrm{~kg}$ batch of each sample for $5 \mathrm{~min}$. before keeping in air-tight bottles. Milling was obtained by using Perten laboratory mill 3100 (Perten instruments, Hagersten, Sweden) equipped with $0.8 \mathrm{~mm}$ sieve and Quadrumat Junior mill (Brabebder $\mathrm{GmbH} \& \mathrm{Co}$ ) with standard sifter mesh size $280 \mu \mathrm{m}$ for wholemeal and white flour respectively. Samples were analyzed for physicochemical, dough and baking properties.

\subsection{Physicochemical characteristics}

Test weight was determined using a standard one litter bucket procedure for wheat. Shrivelled kernels were separated by passing the sample through a sieve with long rounded apertures $1.7 \mathrm{~mm}$ wide. Broken kernels were separated by hand picking from samples. The cleaned and whole grain samples thus obtained were used for the determination of thousand kernel weight. Protein content and zeleny values were determined using NIR technique (Omeg Analyzer G, Bruins instruments). Gluten content, gluten index of white flour and moisture content of whole meal flour were determined according to AACC method no. 38-12 and 44-15A respectively [9]. Hardness index of grains was also evaluated through JYDX $100 \times 40$ Wheat Hardness Index instrument (Courtesy of Sunridge Flour Mill).

The colour of whole meal flours were evaluated by Minolta Chromo Meter CR-300 (Konica Minolta, Tokyo, Japan). Colour parameters were expressed as "L", a* and $b^{*}$. The value of $L$ ( 0 to 100 scale) reflected the brightness and whiteness of whole meal flours; $a^{*}$ and $b^{*}$ values $(-60$ to 60 scale) represented the red to green and yellow to blue colour respectively.

\subsection{Rheological properties of flour}

Brabender Farinograph equipped with $50 \mathrm{~g}$ mixing bowl was used for the evaluation of water absorption (\%), dough development time ( $\mathrm{min}$ ), dough stability (DST) and mixing tolerance index (MTI) of whole meal flour. Alveograph was also used for dough properties of whole meal flour including deformation in energy $(W)$, tenacity or resistance to extension $(\mathrm{P})$, dough extensibility $(\mathrm{L})$ and curve configuration ratio ( $\mathrm{P} / \mathrm{L}$ ratio). These parameters were determined by following AACC method 54-24 and 54-30A respectively [9].

\subsection{Physical characteristics of dough during sheeting}

These characteristics were evaluated by visual estimation of stickiness, resistance to sheeting and shrinkage after sheeting of dough during chapatti making. Properties were scored as Y (low), YY (moderate) and YYY (high).

\subsection{Baking properties}

Whole meal flours (100 g) were used for making Chapatti. Prior to addition of water, flours were mixed with $1 \%$ salt and $5 \%$ oil. The amount of water added to dough was based on percent water absorption evaluated using farinograph. The dough was mixed by a mixer and then allowed to rest for $30 \mathrm{~min} ; 50 \mathrm{~g}$ dough balls was taken and rolled out using a wooden roller into a thin circular sheet of $1 \mathrm{~mm}$ thickness. It was then cut into an $11.5 \mathrm{~cm}$ diameter round sheet and then baked on a preheated $\left(245^{\circ} \mathrm{C}\right)$ round iron plate. After $30 \mathrm{~s}$ discs were inverted and pressed with soft cloth for uniform puffing; inversion of disc was repeated three times after completion of $30 \mathrm{~s}$. Baking process was completed in $90 \mathrm{~s}$, chapatti was packed in polyethylene pouches after cooling to $34{ }^{\circ} \mathrm{C}$ at ambient temperature [10].

\subsection{Textural properties of chapatti}

Mostly in Pakistan chapatti is consumed after $30 \mathrm{~min}$ of baking, therefore textural softness of chapatti was determined by following same time period after baking. Textural measurements (tear force and extensibility) of chapatti were performed using Universal Testing Machine (Model-4464, Buckinghamshire, England) [11]. 


\subsection{Sensory attributes of chapatti}

Chapattis were evaluated for colour, taste, aroma, breakability, chew ability and stickiness after 30 min of baking. Colour was reflected by different scores i.e. 20 (creamy), 16 (amber) 12 (yellow) 8 (light brownish), 4 (dark brownish); taste by 15 (strongly wheat like), 12 (wheat like), 9 (slightly wheat like), 6 (slightly bran like), 3 (strongly bran like); aroma by 15 (strongly wheat like), 12 (wheat like), 9 (slightly wheat like), 6 (trace), 3 (undetectable); breakability by 20 (very easy), 16 (easy), 12 (moderate), 8 (difficult), 4 (very difficult); chewing ability by 20 (very soft), 16 (soft), 12 (semi-hard), 8 (hard), 4 (very hard); stickiness by 10 (non-sticky), 8 (trace), 6 (slightly sticky), 4 (sticky) and 2 (very sticky) [11].

Each sample was evaluated by 14 judges ( 7 males and 7 females from 30 to 47 years age group) for sensory attributes of chapatti. Coded polyethylene pouches retaining half of chapatti were distributed with score cards. Chapatti was assessed in duplicate by each assessor and average value was calculated. Chapattis were rated on the basis of 100 points; $>70$ rated excellent, 60-69 good, 50-59 fair and $<50$ received poor rating.

\subsection{Statistical analysis}

All tests were repeated in triplicate and mean values were stated with standard deviations. Statistical analysis was performed by using SPSS software (SPSS version 17, Inc., USA). Pearson's correlation coefficients were determined between chapatti quality parameters and whole meal flour characteristics to evaluate influence of quality attributes of wheat varieties on chapatti quality. Variations between samples were evaluated by Duncan's test. Least significant difference (LSD) was undertaken to compare mean values at $5 \%$ level of significance.

\section{Results and discussion}

\subsection{Physicochemical properties}

Table 1 demonstrated variation in hardness index, test weight, thousand grains mass, protein content, wet gluten, dry gluten, gluten index, moisture content and zeleny value of wheat varieties. Colour of whole meal flours is another parameter imparts quality effects on intended product, difference in colour of wheat flours were recorded among different varieties (Table 2 ). Protein content was significantly $(P<0.01)$ correlated with wet gluten $(r=0.834)$, dry gluten $(r=0.818)$ and zeleny value $(r=-0.700)$, taste $(r=0.727)$, flour particle size of $>180 \mu \mathrm{m}$ $(r=-0.946),<110 \mu \mathrm{m}(r=0.977)$ and also significantly $(P<0.05)$ correlated with aroma $(r=0.634)$; similarly in different studies significant correlation of gluten (wet and dry) was determined for strong flour; significant negative correlation was evaluated between zeleny value and crude protein $[12,13]$. Flour of fine particle size imparts negative effect on protein percentage [14].

Table 1 Physical and chemical properties of Pakistani wheat varieties and CWMF

\begin{tabular}{|c|c|c|c|c|c|c|c|c|c|}
\hline Varieties & $\mathrm{HI}(\%)$ & TW (Kg/hL) & TGM (g) & PC (\%) & WG (\%) & DG (\%) & $\mathrm{Gl}$ & MC (\%) & $\mathrm{ZS}(\mathrm{mL})$ \\
\hline $\begin{array}{l}\text { Faisal- } \\
\text { abad-08 }\end{array}$ & $77.5 \mathrm{fg} \pm 2.10$ & $79.2 f \pm 1.30$ & $38.4 \mathrm{e} \pm 1.04$ & $10.9 a b \pm 0.13$ & $21.0 b c \pm 0.47$ & $7.0 b c \pm 0.15$ & $68.0 d \pm 2.54$ & $11.8 \mathrm{~cd} \pm 0.15$ & $55.0 \mathrm{~g} \pm 0.24$ \\
\hline Chakwal-50 & $71.1 \mathrm{ab} \pm 1.67$ & $75.8 d \pm 1.17$ & $44.3 \mathrm{k} \pm 1.07$ & $11.1 b c \pm 0.18$ & $20.6 b \pm 0.24$ & $7.0 \mathrm{bc} \pm 0.32$ & $99.0 \mathrm{k} \pm 2.09$ & $11.9 d \pm 0.12$ & $45.0 c \pm 0.17$ \\
\hline Aas-11 & $76.5 f \pm 1.29$ & $80.8 \mathrm{~g} \pm 1.27$ & $39.2 f \pm 1.02$ & $10.2 \mathrm{a} \pm 0.20$ & $17.5 a \pm 0.41$ & $6.0 \mathrm{a} \pm 0.21$ & $95.0 \mathrm{j} \pm 2.50$ & $10.5 a b \pm 0.21$ & $40.0 a \pm 0.14$ \\
\hline Punjab-11 & $78.0 \mathrm{~g} \pm 1.08$ & $74.9 c \pm 1.11$ & $32.4 a \pm 1.09$ & $10.5 a b \pm 0.21$ & $20.0 b \pm 0.26$ & $6.4 a b \pm 0.50$ & $80.0 \mathrm{~g} \pm 1.92$ & $11.0 \mathrm{abcd} \pm 0.19$ & $47.0 d \pm 0.20$ \\
\hline NARC-11 & $72.2 c \pm 2.14$ & $71.0 \mathrm{a} \pm 1.24$ & $36.3 c \pm 1.03$ & $11.7 \mathrm{~cd} \pm 0.09$ & $21.5 b c \pm 0.51$ & $7.0 b c \pm 0.42$ & $77.0 f \pm 2.00$ & $10.9 \pm 0.25$ & $48.0 d \pm 0.15$ \\
\hline Galaxy-13 & $75.1 \mathrm{e} \pm 2.09$ & $75.8 d \pm 1.40$ & $42.1 j \pm 1.00$ & $10.3 a \pm 0.12$ & $20.0 b \pm 0.31$ & $6.5 a b \pm 0.29$ & $84.0 h \pm 2.63$ & $11.2 \mathrm{abcd} \pm 0.30$ & $48.0 d \pm 0.31$ \\
\hline Ujjala-16 & $70.4 a \pm 1.53$ & $76.2 d \pm 1.39$ & $40.2 h \pm 1.03$ & $12.0 \mathrm{de} \pm 0.17$ & $26.0 \mathrm{e} \pm 0.59$ & $8.8 f \pm 0.48$ & $33.0 b \pm 2.11$ & $11.4 b c d \pm 0.29$ & $52.0 f \pm 0.19$ \\
\hline Zincol-16 & $75.0 e \pm 1.88$ & $79.5 f \pm 1.28$ & $39.9 \mathrm{~g} \pm 1.08$ & $10.6 a b \pm 0.14$ & $21.0 b c \pm 0.61$ & $7.1 b c \pm 0.31$ & $71.0 \mathrm{e} \pm 2.41$ & $11.0 \mathrm{abcd} \pm 0.34$ & $43.0 b \pm 0.26$ \\
\hline NIFA-Lalma & $78.0 \mathrm{~g} \pm 1.73$ & $72.5 b \pm 1.16$ & $37.9 d \pm 1.01$ & $10.5 e \pm 0.08$ & $24.0 \mathrm{~d} \pm 0.37$ & $8.1 e \pm 0.48$ & $97.0 \mathrm{k} \pm 2.38$ & $11.0 \mathrm{abcd} \pm 0.18$ & $54.0 \mathrm{~g} \pm 0.35$ \\
\hline Pisabak-13 & $73.8 d \pm 1.39$ & $74.5 c \pm 1.50$ & $38.2 \mathrm{e} \pm 1.06$ & $12.3 \mathrm{de} \pm 0.15$ & $22.5 \mathrm{~cd} \pm 0.41$ & $7.6 c d e \pm 0.52$ & $98.0 \mathrm{k} \pm 2.20$ & $11.0 \mathrm{abcd} \pm 0.24$ & $54.0 \mathrm{~g} \pm 0.16$ \\
\hline Shakkar-13 & $71.6 b c \pm 1.58$ & $79.3 f \pm 1.42$ & $41.8 \mathrm{i} \pm 1.04$ & $11.0 \mathrm{bc} \pm 0.13$ & $23.5 d \pm 0.29$ & $7.9 e \pm 0.19$ & $85.0 h i \pm 2.32$ & $10.6 a b \pm 0.21$ & $58.0 \mathrm{~h} \pm 0.23$ \\
\hline NIA-Amber & $74.5 \mathrm{de} \pm 1.64$ & $74.3 c \pm 1.21$ & $34.4 b \pm 1.07$ & $12.0 \mathrm{de} \pm 0.11$ & $24.0 \mathrm{~d} \pm 0.27$ & $7.8 \mathrm{de} \pm 0.37$ & $60.0 c \pm 2.41$ & $10.8 a b c \pm 0.16$ & $52.0 f \pm 0.14$ \\
\hline TD-1 & $76.0 f \pm 2.08$ & $79.7 f \pm 1.37$ & $47.9 I \pm 1.02$ & $12.5 e \pm 0.19$ & $21.0 b c \pm 0.33$ & $6.9 b c \pm 0.26$ & $22.0 \mathrm{a} \pm 2.30$ & $10.7 a b \pm 0.32$ & $50.0 \mathrm{e} \pm 0.28$ \\
\hline CWMF & $77.9 \mathrm{~g} \pm 1.91$ & $78.0 \mathrm{e} \pm 1.19$ & $41.8 \mathrm{i} \pm 1.00$ & $12.0 \mathrm{de} \pm 0.10$ & $21.0 b c \pm 0.50$ & $6.8 b c \pm 0.41$ & $86.0 \mathrm{i} \pm 2.18$ & $10.2 a \pm 0.26$ & $59.0 h \pm 0.33$ \\
\hline
\end{tabular}

Mean value of replications $(n=4)$ in a column are significantly different $P \leq 0.05$

$H I$ hardness index, TW test weight, TGM thousand grain mass, $P C$ protein content, WG wet gluten, DG dry gluten, $G I$ gluten index, $M C$ moisture content, ZS zeleny

Alphabets demonstrated differences among mean values of different varieties for same parameter. Close values were placed in same group by Duncan's test (by using SPSS software version 17, Inc., USA.) and demonstrated by same alphabet 
Table 2 Color of flour obtained from Pakistani wheat varieties and CWMF

\begin{tabular}{|c|c|c|c|}
\hline \multirow[t]{2}{*}{ Varieties } & \multicolumn{3}{|l|}{ Color } \\
\hline & L & $a^{*}$ & $b^{*}$ \\
\hline Faisalabad-08 & $85.3 \pm 0.90$ & $1.0 \pm 0.14$ & $11.4 \pm 0.35$ \\
\hline Chakwal-50 & $85.2 \pm 0.99$ & $0.98 \pm 1.86$ & $11.0 \pm 0.34$ \\
\hline Aas-11 & $83.5 \pm 0.99$ & $1.1 \pm 0.13$ & $10.9 \pm 0.38$ \\
\hline Punjab-11 & $84.7 \pm 1.13$ & $1.1 \pm 0.13$ & $10.3 \pm 0.42$ \\
\hline NARC-11 & $84.1 \pm 0.79$ & $0.99 \pm 0.21$ & $10.5 \pm 0.29$ \\
\hline Galaxy-13 & $83.7 \pm 0.85$ & $1.0 \pm 0.19$ & $10.7 \pm 0.38$ \\
\hline Ujjala-16 & $84.9 \pm 0.87$ & $0.98 \pm 0.30$ & $11.1 \pm 0.40$ \\
\hline Zincol-16 & $83.5 \pm 1.15$ & $0.99 \pm 1.22$ & $10.4 \pm 0.43$ \\
\hline NIFA-Lalma & $84.7 \pm 1.18$ & $0.97 \pm 0.21$ & $11.2 \pm 0.39$ \\
\hline Pisabak-13 & $84.1 \pm 0.87$ & $1.0 \pm 0.13$ & $10.6 \pm 0.41$ \\
\hline Shakkar-13 & $83.8 \pm 1.18$ & $1.2 \pm 0.91$ & $10.9 \pm 0.38$ \\
\hline NIA-Amber & $84.3 \pm 1.10$ & $1.1 \pm 0.79$ & $11.2 \pm 0.45$ \\
\hline TD-1 & $85.3 \pm 0.96$ & $1.1 \pm 0.17$ & $11.0 \pm 0.33$ \\
\hline CWMF & $84.8 \pm 1.40$ & $1.2 \pm 0.27$ & $10.6 \pm 0.44$ \\
\hline
\end{tabular}

Mean value of replications $(n=4)$ in a column are significantly different $\mathrm{P} \leq 0.05$

$\mathrm{L}=$ whiteness and brightness, $\mathrm{a}^{*}=$ red and green, $\mathrm{b}^{*}=$ yellow and blue color of whole meal flour

Wet gluten was significantly $(P<0.01)$ correlated with protein content $(r=0.834)$, dry gluten $(r=0.980)$, colour $(r=-0.694)$, taste $(r=0.873)$, aroma $(r=0.769)$, flour particle size of $>180 \mu \mathrm{m}(r=-0.733)$, flour particle size of $<110 \mu \mathrm{m}(r=0.846)$ and significantly correlated with water absorption $(r=-0.555)$ at significance level $P<0.05$; dry gluten was significantly $(P<0.01)$ correlated with protein content $(r=0.818)$, wet gluten $(r=0.980)$, colour $(r=-0.708)$, taste $(r=0.921)$, aroma $(r=0.846)$, flour particle size of $>180 \mu \mathrm{m}(r=-0.748)$, flour particle size of $<110 \mu \mathrm{m}$ $(r=0.839)$ and significantly correlated $(-0.611)$ with water absorption at significance level $P<0.05$; gluten index was significantly $(P<0.01)$ correlated with dough development time $(r=0.779), P$-value $(r=0.691)$, handling (stickiness) $(r=0.836)$, resistance to sheeting $(r=-0.805)$ and significantly correlated with DST $(r=0.649)$, MTI $(r=-0.583)$ at significance level $P<0.05$.

In previous research works, wet gluten and dry gluten were significantly correlated with water absorption whereas gluten index had significant correlation with dough stability time and dough development time of wheat varieties retaining bread making potential [15]. A study reflected that whole wheat flour of coarser particles affect gluten network and baking properties [16]. Similarly positive correlation was recorded between wet gluten content and sensory attributes of crackers [17]. A study revealed decrease in dough stability, increase in dough softening, variation in mixing and pasting properties of dough by changing concentration of gluten units [18].
Zeleny value was significantly $(P<0.01)$ correlated with protein content $(r=0.700)$, flour particle size of $>180 \mu \mathrm{m}$ $(r=-0.719)$, flour particle size of $<110 \mu \mathrm{m}(r=0.699)$ and correlated with wet gluten $(r=0.583)$, flour particle size of $130-180 \mu \mathrm{m}(r=0.541)$ at significance level $P<0.05$. Similarly significant correlation was determined between sedimentation value and protein of whole wheat flour and wheat flour used for cookies making [19]. In a study higher sedimentation value was recorded in fine flour as compare to coarser frictions [20].

Particle size distribution reflects granulation of material which imparts effect on physicochemical and rheological properties of wheat flour. Figure 1 demonstrated particle size distribution of flours; Aas-11, NARC-11, and TD-1 produced highest coarser particles $(>180 \mu \mathrm{m})$ and Ujjala-16, Shakkar-13, NIA-Sarang and CWMF flour had maximum values of fine particles $(<110 \mu \mathrm{m})$. In previous study it was determined that flour particle size from different milling machines influenced physicochemical and rheological properties of wheat flour [21].

\subsection{Rheological parameters}

Farinograph and alveograph were used to evaluate rheology of dough made by flour of different wheat varieties including commercial wholemeal flour; farinograph results of different flour demonstrated variation in water absorption, dough development time, dough stability time and mixing tolerance index of dough from different wheat varieties (Table 3). Farinograph reflected wheat flour characteristics and dough development time have increased with increase in water absorption and protein content. Water absorption was significantly $(P<0.05)$ correlated with wet gluten $(r=-0.555)$, dry gluten $(r=-0.611), W$-value $(r=0.590)$, colour $(r=0.545)$ and aroma $(r=-0.650)$, correlated with taste $(r=-0.680)$ of chapatti at significant level of $P<0.01$. Dough development time demonstrated significant $(P<0.01)$ correlation with gluten index $(r=0.779)$, dough stability time $(r=0.852)$, particle size of 130-180 $\mu \mathrm{m}(r=0.756)$, whereas significantly $(P<0.01)$ correlated with mixing tolerance index $(r=-0.646)$, handling (stickiness) of dough $(r=0.625)$ and resistance to sheeting of dough $(r=-0.636)$. Dough stability time was significantly $(P<0.01)$ correlated with dough development time $(r=0.852)$, mixing tolerance index $(r=-0.806)$, particle size of 130-180 $\mu \mathrm{m}$ and correlated with gluten index $(r=0.649)$, resistance to sheeting of dough $(r=0.572)$ and particle size of 180 at significant level of $P<0.05$. Mixing tolerance index was significantly $(P<0.05)$ correlated with gluten index $(r=-0.583)$, dough development time $(r=-0.646)$, handling (stickiness) ( $r=-0.622)$ and correlated with dough stability time $(r=-0.806)$ and resistance to sheeting of dough $(r=0.764)$ at significant level of $P<0.01$. 
Table 3 Rheological properties of Pakistani wheat varieties and CWMF

\begin{tabular}{|c|c|c|c|c|c|c|c|c|}
\hline \multirow[t]{2}{*}{ Varieties } & \multicolumn{4}{|c|}{ Farinograph (whole meal) } & \multicolumn{4}{|c|}{ Alveograph (whole meal) } \\
\hline & $\mathrm{A}(\%)$ & $\mathrm{DDT}(\min )$ & DST (min) & $\mathrm{MTI}(\mathrm{BU})$ & $\mathrm{P}(\mathrm{mm})$ & $\mathrm{L}(\mathrm{mm})$ & $\mathrm{W}\left(10^{-4} \mathrm{~J}\right)$ & $\mathrm{P} / \mathrm{L}$ \\
\hline $\mathrm{ad}-08$ & $72.2 \mathrm{de} \pm 0.24$ & $4.5 \mathrm{cde} \pm 0.17$ & $3.2 \mathrm{~cd} \pm 0.16$ & $58 f \pm 2.07$ & $76 e \pm 1.73$ & $29 f \pm 3.14$ & $194 I \pm 3.05$ & $1.10 \mathrm{a} \pm 0.55$ \\
\hline Chakwal-50 & $70.4 a b c d \pm 0.17$ & $5 g h \pm 0.13$ & $6.5 \mathrm{~g} \pm 0.24$ & $38 b \pm 1.62$ & $89 \mathrm{~g} \pm 2.51$ & $33 \mathrm{~h} \pm 2.09$ & $114 \mathrm{~h} \pm 2.79$ & $2.70 \mathrm{~d} \pm 1.20$ \\
\hline Aas-11 & $70.4 a b c d \pm 0.19$ & $4.4 \mathrm{bcd} \pm 0.25$ & $3.6 \mathrm{~d} \pm 0.21$ & $45 d \pm 1.35$ & $115 j \pm 2.38$ & $21 c \pm 153$ & $100 f \pm 2.42$ & $5.48 \mathrm{j} \pm 0.02$ \\
\hline Punjab-11 & $70.9 \mathrm{bcd} \pm 0.26$ & $.0 \mathrm{bc} \pm 0.18$ & $2.7 a b c \pm 0.15$ & $58 f \pm 2.14$ & $125 \mathrm{k} \pm 3.09$ & $24 \mathrm{de} \pm 178$ & $124 j \pm 3.18$ & $5.21 i \pm 0.02$ \\
\hline NARC-11 & $69.0 a b c \pm 0.33$ & $4.4 \mathrm{bcd} \pm 0.23$ & $4.4 \mathrm{e} \pm 0.20$ & $56 e \pm 3.06$ & $103 \mathrm{~h} \pm 3.14$ & $17 a \pm 143$ & $76 d \pm 1.72$ & $6.06 \mathrm{k} \pm 0.02$ \\
\hline Galaxy-13 & $71.5 \mathrm{cde} \pm 0.35$ & $4.2 b c \pm 0.21$ & $3.0 b c \pm 0.11$ & $67 \mathrm{~h} \pm 2.21$ & $103 \mathrm{~h} \pm 4.06$ & $17 a \pm 1.69$ & $79 \mathrm{e} \pm 1.91$ & $6.06 \mathrm{k} \pm 2.40$ \\
\hline Ujjala-16 & $68.2 \mathrm{ab} \pm 0.18$ & $3.7 a b \pm 0.14$ & $3.2 \mathrm{~cd} \pm 0.17$ & $65 \mathrm{~g} \pm 2.15$ & $66 c \pm 1.99$ & $19 b \pm 2.30$ & $53 b \pm 2.61$ & $3.47 f \pm 0.87$ \\
\hline Zincol-16 & $68.2 \mathrm{ab} \pm 0.27$ & $4.7 \mathrm{cdef} \pm 0.07$ & $5.3 f \pm 0.23$ & $32 a \pm 1.53$ & $87 f \pm 2.26$ & $25 e \pm 3.14$ & $79 \mathrm{e} \pm 2.85$ & $3.48 f \pm 0.72$ \\
\hline NIFA-Lalma & $68.5 \mathrm{ab} \pm 0.41$ & $6.0 \mathrm{~h} \pm 0.20$ & $6.7 \mathrm{~g} \pm 0.21$ & $37 b \pm 1.93$ & $116 j \pm 4.09$ & $25 e \pm 2.75$ & $118 i \pm 3.04$ & $4.64 \mathrm{~h} \pm 1.49$ \\
\hline Pisabak-13 & $70.8 \mathrm{bcd} \pm 0.43$ & $5.0 \mathrm{defg} \pm 0.17$ & $6.6 \mathrm{~g} \pm 0.20$ & $42 c \pm 2.03$ & $153 I \pm 4.15$ & $23 d \pm 2.96$ & $152 \mathrm{k} \pm 2.29$ & $6.65 I \pm 1.40$ \\
\hline Shakkar-13 & $67.6 a \pm 0.38$ & $5.2 e f g \pm 0.14$ & $5.3 f \pm 0.24$ & $41 c \pm 2.00$ & $63 b \pm 3.82$ & $31 \mathrm{~g} \pm 3.08$ & $75 d \pm 1.81$ & $2.03 b \pm 1.24$ \\
\hline VIA-Amber & $70.0 \mathrm{abcd} \pm 0.40$ & $3.3 a \pm 0.05$ & $2.6 a b \pm 0.19$ & $74 i j \pm 3.57$ & $71 d \pm 2.97$ & $28 f \pm 2.04$ & $62 c \pm 2.03$ & $2.54 c \pm 1.46$ \\
\hline TD-1 & $69.9 \mathrm{abcd} \pm 0.22$ & $3.2 \mathrm{a} \pm 0.21$ & $2.4 a \pm 0.16$ & $73 i \pm 2.28$ & $60 a \pm 2.81$ & $19 b \pm 1.83$ & $45 a \pm 1.90$ & $3.16 \mathrm{e} \pm 1.54$ \\
\hline CWMF & $71.5 \mathrm{cde} \pm 0.34$ & $5.4 f g h \pm 0.19$ & $4.1 \mathrm{e} \pm 0.21$ & $75 j \pm 3.01$ & $111 \mathrm{i} \pm 4.06$ & $25 e \pm 1.96$ & $112 \mathrm{~g} \pm 3.02$ & $4.44 \mathrm{~g} \pm 2.07$ \\
\hline
\end{tabular}

Mean value of replications $(\mathrm{n}=4)$ in a column are significantly different $P \leq 0.05$

WA water absorption, DDT dough development time, DST dough stability, MTI mixing tolerance index, $P$ tenacity, $L$ dough extensibility, $W$ baking strength, $P / L$ configuration ratio

Alphabets demonstrated differences among mean values of different varieties for same parameter. Close values were placed in same group by Duncan's test (by using SPSS software version 17, Inc., USA.) and demonstrated by same alphabet

A study on wheat varieties had shown significant correlation between water absorption and W-value of nonbread wheat [22]. Similar research work as above regarding sensory attributes had been conducted for evaluating sensory and textural properties of chapatti [23]. Significant correlation of wet and dry gluten was recorded with water absorption and dough stability during study on quality of wheat flour [24]. In a study significant correlation was determined between dough development and dough stability time; whereas mixing tolerance index indicated significantly negative correlation [25]. Research findings revealed that dough development time significantly decreased and dough stability time significantly increased by reducing particles size of wheat flour [26]. A study reflected significant correlation of dough development and dough stability time with stickiness of dough; glutenin was associated with dough strength as improvement in dough strength resulted in reduction of stickiness [27].

In this study alveograph reflected that flour of different wheat varieties varied in $P$-value, $L$-value, $\mathrm{W}$-value and $P / L$ ratio (Table 3 ) had mark able impact on sheeting behaviour after resting of dough. Alveographic parameter $P$-value was significantly $(P<0.01)$ correlated with gluten index $(r=0.691), P / L$ ratio $(r=0.808)$, moisture content of chapatti after $30 \mathrm{~min}$ of storage $(r=0.737)$; L-value was significantly $(P<0.01)$ correlated with $W$-value $(r=0.703)$, $P / L$ ratio $(r=-0.674)$, chewing ability $(r=0.867)$ and had significant correlation $(P<0.05)$ with extensibility of chapatti after $30 \mathrm{~min}$ of storage $(r=-0.596)$, breakability of chapatti $(r=0.645)$, stickiness $(r=-0.600)$; W-value was significantly $(P<0.001)$ correlated with $L$-value $(r=0.590)$, stickiness of dough $(r=0.723)$, resistance to sheeting of dough $(-0.663)$ and correlated with water absorption of flour $(r=0.590)$, chewing ability of chapatti $(r=0.563)$ at significance level of $P<0.001 ; P / L$ ratio was significantly $(P<0.005)$ correlated with moisture content of chapatti after $30 \mathrm{~min}$ of storage $(r=0.567)$, chewing ability $(r=-0.586)$, particle size of $110-130 \mu \mathrm{m}(r=0.570)$ and also significantly $(P<0.01)$ correlated with $P$, L values $(r=0.808$, $-0.674)$ respectively.

In a research finding significant correlation was determined between $P / L$ and water absorption of Romanian wheat; W-value was significantly correlated with water absorption of wheat flour; significant correlation was recorded between $P / L$ and particle size index of flour obtained from winter wheat [28]. A study reflected significant correlation between alveographic parameters and sensory characteristics of intended product made by wheat flour containing small portion of rice bran [29]. Another study on wheat flour quality reflected significant correlation between $P-P / L, W-L, W-W a b s, P / L-P$ and $L$ [30]. 


\subsection{Physical behaviour of dough during sheeting}

Wheat varieties NARC-11, Ujalla-16 and TD-1 reflected maximum resistance to sheeting, shrinkage after sheeting and low stickiness; Punjab-11, Galaxy-13 and CWMF had moderate resistance to sheeting, stickiness and shrinkage after sheeting; Faisalabad-08, Chakwal-50, Zincol-16, NIFA-Lalma, Pisabak-13 and Shakkar-13 demonstrated minimum resistance to sheeting and shrinkage after sheeting (Table 4). Flour of NARC-11 and Galaxy-13 had maximum dough strength; whereas flour of Chakwal-50 and Shakkar-13 had minimum dough strength as previous study revealed that dough strength and dough extensibility was negatively correlated [11].

\subsection{Organoleptic evaluation}

In Pakistan chapatti is consumed as a major part of diet in fresh form within 30 to $60 \mathrm{~min}$; mostly baking products are consumed after long storage as time is require to supply at consumer end. Creamy colour, softness and pliability of structure are indicator of fresh product during storage. Reduction in extensibility and increase in deformation modules of chapatti are common during long storage. Pakistani wheat cultivars were milled to prepare chapattis that were judged by panel of 18 members to score from fair to excellent (Table 5). Colour, taste, aroma, breakability, chewing ability and stickiness of chapatti were considered for total score and overall acceptability.

Panellist's score for sensory properties in term of texture demonstrated significant $(P<0.01)$ correlation $r=0.771$ between break ability and chewiness of chapatti. Estimation of flour suitability for intended purpose, correlation between physicochemical parameters and chapatti quality has reflected the significance of these tests as reported in previous study [31, 32].
Table 4 Physical attributes of dough, backing properties of chapatti from Pakistani wheat varieties and CWMF

\begin{tabular}{|c|c|c|c|c|c|c|}
\hline \multirow[t]{2}{*}{ Varieties } & \multicolumn{3}{|c|}{$\begin{array}{l}\text { Physical properties of dough during } \\
\text { sheeting }\end{array}$} & \multicolumn{3}{|c|}{$\begin{array}{l}\text { Baking properties of chapatti after } 30 \mathrm{~min} \text {. } \\
\text { of storage }\end{array}$} \\
\hline & $\begin{array}{l}\text { Handling } \\
\text { (stickiness) }\end{array}$ & $\begin{array}{l}\text { Resistance } \\
\text { to sheeting }\end{array}$ & $\begin{array}{l}\text { Shrinkage } \\
\text { after sheet- } \\
\text { ing }\end{array}$ & MC (\%) & TF (MPa) & $\mathrm{EX}(\mathrm{mm})$ \\
\hline Faisalabad-08 & YYY & $\mathrm{Y}$ & Y & $21.3 b \pm 0.16$ & $3.3 c \pm 0.25$ & $12.3 \mathrm{i} \pm 0.59$ \\
\hline Chakwal-50 & YYY & $\mathrm{Y}$ & $\mathrm{Y}$ & $21.0 \mathrm{ab} \pm 0.23$ & $4.2 d \pm 0.30$ & $13.4 j \pm 3.21$ \\
\hline Aas-11 & YYY & YY & YY & $26.1 \mathrm{~g} \pm 0.31$ & $3.7 c \pm 0.27$ & $6.5 \mathrm{def} \pm 1.78$ \\
\hline Punjab-11 & YY & YY & YY & $25.2 f \pm 0.14$ & $2.7 b \pm 0.46$ & $6.8 \mathrm{ef} \pm 1.89$ \\
\hline NARC-11 & $\mathrm{Y}$ & YYY & YYY & $22.8 d \pm 0.15$ & $1.9 \mathrm{a} \pm 0.26$ & $6.4 \mathrm{de} \pm 1.95$ \\
\hline Galaxy-13 & YY & YY & YY & $23.9 \mathrm{e} \pm 0.18$ & $4.7 e \pm 0.41$ & $5.9 b \pm 2.09$ \\
\hline Ujjala-16 & $\mathrm{Y}$ & YYY & YYYY & $21.8 c \pm 0.30$ & $5.2 f \pm 0.24$ & $6.2 \mathrm{~cd} \pm 3.60$ \\
\hline Zincol-16 & YYY & $\mathrm{Y}$ & $\mathrm{Y}$ & $26.3 \mathrm{~g} \pm 0.18$ & $5.8 \mathrm{~g} \pm 0.19$ & $10.6 \mathrm{~g} \pm 3.06$ \\
\hline NIFA-Lalma & YYY & $\mathrm{Y}$ & $\mathrm{Y}$ & $25.9 \mathrm{~g} \pm 0.25$ & $12.0 \mathrm{~h} \pm 0.41$ & $11.1 \mathrm{~h} \pm 2.15$ \\
\hline Pisabak-13 & YYY & $\mathrm{Y}$ & $\mathrm{Y}$ & $30.7 \mathrm{~h} \pm 0.26$ & $5.1 \mathrm{ef} \pm 0.27$ & $6.9 f \pm 2.35$ \\
\hline Shakkar-13 & YYY & $\mathrm{Y}$ & $\mathrm{Y}$ & $26.3 \mathrm{~g} \pm 0.19$ & $5.1 \mathrm{ef} \pm 0.18$ & $13.5 j \pm 2.87$ \\
\hline NIA-Amber & $\mathrm{Y}$ & YY & YY & $22.0 c \pm 0.11$ & $3.3 c \pm 0.42$ & $11.9 \mathrm{i} \pm 2.51$ \\
\hline TD-1 & $\mathrm{Y}$ & YYY & YY & $20.8 a \pm 0.15$ & $3.3 c \pm 0.26$ & $4.8 a \pm 1.84$ \\
\hline CWMF & YY & YY & YY & $26.1 \mathrm{~g} \pm 0.22$ & $4.7 i \pm 0.32$ & $7.2 \mathrm{~h} \pm 2.62$ \\
\hline
\end{tabular}

Mean value of replications $(n=4)$ in a column are significantly different $P \leq 0.05$

$\mathrm{Y}(1)=$ low, $Y Y(2)=$ moderate, $Y Y Y(3)=$ high,$M C=$ moisture content, $T F=$ tear force, $E X=$ extensibility 
Table 5 Organoleptic evaluation of chapatti made from Pakistani wheat varieties and CWMF

\begin{tabular}{|c|c|c|c|c|c|c|c|c|}
\hline Varieties & Colour & Taste & Aroma & Breakability & Chewingability & Stickiness & Total score & $\begin{array}{l}\text { Overall } \\
\text { acceptability }\end{array}$ \\
\hline Faisalabad-08 & $18.2 \pm 1.65 a$ & $9.1 \pm 1.43 a$ & $8.8 \pm 1.72 a b$ & $9.7 \pm 1.29 a b$ & $10.4 \pm 1.23 a b$ & $6.1 \pm 0.19 \mathrm{def}$ & $62.3 \pm 7.51 a$ & Good \\
\hline Chakwal-50 & $18.1 \pm 1.42 a$ & $9.3 \pm 1.27 a$ & $8.7 \pm 1.51 \mathrm{ab}$ & $8.4 \pm 0.79 a$ & $9.5 \pm 1.60 a$ & $7.3 \pm 0.17 \mathrm{~g}$ & $61.3 \pm 6.76 a$ & Good \\
\hline Aas-11 & $16.5 \pm 0.91 a$ & $10.1 \pm 1.20 \mathrm{a}$ & $9.4 \pm 1.47 a b$ & $10.1 \pm 1.30 \mathrm{abc}$ & $10.6 \pm 1.54 a b$ & $5.9 \pm 0.30 c d e f$ & $62.6 \pm 6.72 a$ & Good \\
\hline Punjab-11 & $17.8 \pm 1.33 a$ & $10.3 \pm 0.94 a$ & $9.5 \pm 1.28 a b$ & $14.2 \pm 1.60 d$ & $14.3 \pm 0.84 b$ & $4.5 \pm 0.29 a b$ & $70.6 \pm 6.28 a$ & Excellent \\
\hline NARC-11 & $17.2 \pm 1.34 a$ & $9.4 \pm 1.31 a$ & $8.2 \pm 1.36 a$ & $14.2 \pm 1.50 \mathrm{~d}$ & $10.9 \pm 1.47 a b$ & $5.1 \pm 0.38 b c$ & $65.0 \pm 7.36 a$ & Good \\
\hline Galaxy-13 & $16.6 \pm 1.65 a$ & $10.7 \pm 1.25 a$ & $9.8 \pm 1.46 a b$ & $14.0 \pm 1.50 \mathrm{~cd}$ & $10.8 \pm 1.52 \mathrm{ab}$ & $5.3 \pm 0.36 b c d e$ & $67.2 \pm 7.74 a$ & Excellent \\
\hline Ujjala-16 & $16.8 \pm 1.33 a$ & $9.7 \pm 1.29 a$ & $8.2 \pm 1.61 a$ & $12.3 \pm 1.41 \mathrm{abcd}$ & $10.1 \pm 1.38 a$ & $4.0 \pm 0.27 a$ & $61.1 \pm 7.29 a$ & Good \\
\hline Zincol-16 & $16.5 \pm 1.71 a$ & $10.5 \pm 1.26 a$ & $9.9 \pm 1.81 \mathrm{ab}$ & $9.5 \pm 1.19 a b$ & $10.3 \pm 1.29 a b$ & $6.2 \pm 0.32 \mathrm{ef}$ & $62.9 \pm 7.58 a$ & Good \\
\hline NIFA-Lalma & $17.4 \pm 1.52 a$ & $9.6 \pm 1.41 a$ & $8.0 \pm 1.70 a$ & $13.9 \pm 1.28 \mathrm{~cd}$ & $11.0 \pm 1.49 a b$ & $5.0 \pm 0.45 b c$ & $64.9 \pm 7.85 a$ & Good \\
\hline Pisabak-13 & $17.3 \pm 0.94 a$ & $9.6 \pm 0.86 a$ & $8.5 \pm 0.98 a$ & $14.1 \pm 1.38 \mathrm{~cd}$ & $11.1 \pm 1.15 a b$ & $5.0 \pm 0.42 b c$ & $65.6 \pm 5.73 a$ & Good \\
\hline Shakkar-13 & $16.7 \pm 1.17 a$ & $10.1 \pm 1.35 a$ & $10.4 \pm 1.19 a b$ & $8.6 \pm 1.37 a$ & $9.7 \pm 1.52 a$ & $7.2 \pm 0.40 \mathrm{~g}$ & $62.7 \pm 7.00 a$ & Good \\
\hline NIA-Amber & $16.8 \pm 1.58 a$ & $9.4 \pm 1.31 a$ & $8.2 \pm 1.36 a$ & $14.2 \pm 1.50 \mathrm{~d}$ & $10.9 \pm 1.47 a b$ & $5.1 \pm 0.38 b c$ & $64.6 \pm 7.60 a$ & Good \\
\hline TD-1 & $18.0 \pm 1.24 a$ & $9.8 \pm 1.38 a$ & $8.3 \pm 1.32 a$ & $9.2 \pm 1.31 \mathrm{a}$ & $10.1 \pm 0.78 a$ & $6.4 \pm 0.29 \mathrm{fg}$ & $61.8 \pm 6.32 a$ & Good \\
\hline CWMF & $17.2 \pm 1.43 a$ & $12.5 \pm 1.30 \mathrm{a}$ & $13.0 \pm 1.60 b$ & $13.5 \pm 1.47 \mathrm{bcd}$ & $10.8 \pm 1.45 a b$ & $5.2 \pm 0.26 \mathrm{bcd}$ & $72.2 \pm 7.51 \mathrm{a}$ & Excellent \\
\hline
\end{tabular}

Mean value of replications $(n=4)$ in a column are significantly different $P \leq 0.05$

Alphabets demonstrated differences among mean values of different varieties for same parameter. Close values were placed in same group by Duncan's test (by using SPSS software version 17, Inc., USA.) and demonstrated by same alphabet

\subsection{Texture of chapatti}

Texture of chapatti was estimated by determining the softness through Instron Universal Testing Machine. Extensibility and tear force of chapatti were determined after $30 \mathrm{~min}$ of storage. Wheat variety Shakkar-13 had maximum extensibility as compare to TD- 1 with minimum extensibility of chapatti (Table 4). Similar results were recorded in a study conducted to determine the instrumental texture of chapatti [11]. This test provided clear differences that could be utilized for segregation of wheat varieties.

\section{Conclusion}

Thirteen Pakistani wheat varieties and CWMF had been selected to evaluate most suitable wheat flour/flours for chapatti making by determining physicochemical, rheological properties and sensory attributes. Moderate stickiness, sheeting ability and contraction after sheeting of dough were evaluated in Punjab-11, Galaxy-13 and commercial wholemeal flour reflected easy to handle. Dough from other varieties i.e. NARC-11, Ujalla-16 and TD- 1 had comparatively low sheeting ability; Faisalabad-08, Chakwal-50, Zincol-16, NIFA-Lalma, Pisabak-13 and Shakkar-13 having maximum stickiness, made them not easy to handle as compare to Punjab-11, Galaxy-13 and CWMF. Sensory characteristics reflected that all selected Pakistani wheat varieties were suitable for chapatti making but few (Punjab-11 and Galacy-13) including CWMF were found to be excellent for intended purpose.
Acknowledgements Our appreciation is extensive to Lab Assistants of Food Quality Labs at Food Quality and Safety Research Institute for technical support.

Funding This study was funded by "The International Maize and Wheat Improvement Centre (CIMMYT) (Grant No. ALP-2016)".

\section{Compliance with ethical standards}

Conflict of interest Authors confirmed that they have no conflict of interest.

\section{References}

1. Gujral HS, Singh GS, Rosell CM (2008) Extending shelf life of chapatti by partial baking and frozen storage. J Food Eng. https ://doi.org/10.1016/j.jfoodeng.2008.05.027

2. Safdar MN, Naseem K, Siddiqui N, Amjad M, Hameed T, Khalil $S$ (2009) Quality evaluation of different wheat varieties for the production of unleavened flat bread (chapatti). Pak J Nutr. https://scialert.net/abstract/?doi=pjn.2009.1773.1778

3. Srivastava AK, Meyer D, Rao HP, Seibel W (2002) Scanning electron microscopic study of dough and chapatti from gluten reconstituted good and poor quality flour. Cereal Sci. https:// doi.org/10.1006/jcrs.2001.0432

4. Rehman S, Paterson A, Hussain S, Bhatti IA, Shahid MAR (2006) Influence of detoxified Indian vetch (Lathyrus Sativus L.) on sensory and protein quality characteristics of composite flour chapatti. J Sci of Food and Agric. https://doi.org/10.1002/ jsfa. 2481

5. Porai ESE, Salama AE, Sharaf AM, Hegazy Al, Gadallah MGE (2013) Effect of different milling processes on Egyptian wheat flour properties and pan bread quality. Ann Agric Sci. https:// doi.org/10.1016/j.aoas.2013.01.008 
6. Prabhasankar P (2002) Electrophoretic and immunochemical characteristics of wheat protein fractions and their relationships to chapatti making quality. Food Chem. https://doi. org/10.1016/S0308-8146(01)00388-0

7. Shewry PR, Sandra JH (2015) The contribution of wheat to human diet and health. Food Energy Secur. https://doi. org/10.1002/fes3.64

8. Salehifar M, Ardebili MS, Azizi MH (2010) Effect of wheat flour protein variations on sensory attributes, texture and staling of Taftoon bread. Cienc Tecnol Aliment. https://doi.org/10.1590/ S0101-20612010000300041

9. AACC (2000) Approved method of the American Association of Cereal Chemists. AACC, St. Paul

10. Rehman S, Paterson A, Piggott JR (2006) Optimisation of chapatti textural quality using British wheat cultivar flours. Int J Food Sci Technol. https://doi.org/10.111 1/j.1365-2621.2006.01250.x

11. Gujral HS, Gaur S (2007) Instrumental texture of chapati as affected by barley flour, glycerol monostearate and sodium chloride. Int J Food Prop. https://doi.org/10.1081/JFP-20005 9492

12. Zaidel DNA, Chin NL, Yusof YA, Rahman RA (2009) Analysis and correlation studies on gluten quantity and quality during production. J Appl Sci. https://scialert.net/abstract/?doi =jas.2009.1686.1694

13. Pasha I, Anjum FM, Butt MS, Sultan JI (2007) Gluten quality prediction and correlation studies in spring wheats. J Food Quality. https://doi.org/10.1111/j.1745-4557.2007.00133.x

14. Choi HW, Baik BK (2013) Significance of wheat flour particle size on sponge cake baking quality. Cereal Chem. https://doi. org/10.1094/CCHEM-07-12-0088-R

15. Dhaka V, Khatkar BS (2015) Effects of gliadin/glutenin and hmw-gs/lmw-gs ratio on dough rheological properties and bread-making potential of wheat varieties. J Food Qual. https ://doi.org/10.1111/jfq.12122

16. Bressiani J, Oro T, Lopes PM, Silva D, Montenegro FM, Bertolin TE, Gutkoski LC, Gularte MA (2019) Influence of milling whole wheat grains and particle size on thermo-mechanical properties of flour using Mixolab. Czech J Food Sci. https://doi. org/10.17221/239/2018-CJFS

17. Osella CA, Robutti J, Sanchez HD, Borras F, Torre MA (2008) Dough properties related to baking quality using principal component analysis. Cienc Tecnol Aliment. https://doi. org/10.1080/11358120809487633

18. Barak S, Mudgil D, Khatkar BS (2014) Influence of gliadin and glutenin fractions on rheological, pasting, and textural properties of dough. Int J Food Prop. https://doi. org/10.1080/10942912.2012.717154

19. Ram S, Singh RP (2003) Solvent retention capacities of Indian wheats and their relationship with cookie-making quality. Cereal Chem. https://doi.org/10.1094/CCHEM.2004.81.1.128

20. Suresh D, Sakhare A, Inamdar A, Soumya C, Indrani D, Rao GV (2014) Effect of flour particle size on microstructural, rheological and physico-sensory characteristics of bread and South Indian parotta. J Food Sci Technol. https://doi.org/10.1007/s1319 7-013-0939-5

21. Kang MJ, Kim MJ, Kwak HS, Kim SS (2019) Effects of milling methods and cultivars on physicochemical properties of wholewheat flour. J Food Qual. https://doi.org/10.1155/2019/3416905

22. Konopka I, Fornal L, Abramczyk D, Rothkaehl J, Rotkiewicz D (2004) Rotkiewicz, Statistical evaluation of different technological and rheological tests of Polish wheat varieties for bread volume prediction. Int J Food Sci Technol. https://doi.org/10.11 11/j.1365-2621.2004.00741.x

23. Khurshid S, Arif S, Iqbal HM, Akbar QU, Yousaf S (2019) Chapatti sensory and textural quality in relation to whole meal flour and dough characteristics. Food Sci Biotechnol. https://doi. org/10.1007/s10068-019-00658-w

24. Berehoiu RMT, Popa CN, Visan LV, Simion V, Dobrinoiu RV, Guidea SMD (2018) Farinograph versus alveograph in predictive modelling of wheat flours quality. Sciendo. https://doi.org/10.2478/ alife-2018-0092

25. Xhabiri GQ, Durmishi N, Idrizi X, Ferati I, Hoxha I (2016) Rheological qualities of dough from mixture of flour and wheat bran and possible correlation between bra bender and mixolab chopin equipments. Food Process Technol. https://doi.org/10.15406/ mojfpt.2016.02.00042

26. Wang N, Hou GG, Dubat A (2017) Effects of flour particle size on the quality attributes of reconstituted whole-wheat flour and Chinese southern-type steamed bread. Food Sci Technol. https ://doi.org/10.1016/j.Iwt.2017.04.025

27. Zhu J, Huang S, Khan K, Brien LO (2001) Relationship of protein quantity, quality and dough properties with Chinese steamed bread quality. J Cereal Sci. https://doi.org/10.1006/ jcrs.2000.0358

28. Szabo BP, Gyimes E, Veha A, Horvath ZH (2016) Flour quality and kernel hardness connection in winter wheat. Acta Univ Sapientiae Aliment. https://doi.org/10.1515/ausal-2016-0003

29. Ashraf S, Saeed SMG, Sayeed SA, Ali R, Saeed H, Ahmed M (2012) Effect of fat-replacement through rice milling by products on the rheological and baking behaviour of dough. Afr J Agric Res. https://doi.org/10.5897/AJAR12.1052

30. Berehoiu RMT, Popa CN, Visan LV, Simion V, Dobrinoiu RV, Guidea SMD (2018) Guidea, Farinograph versus alveograph in predictive modelling of wheat flours quality. Sciendo. https://doi. org/10.2478/alife-2018-0092

31. Nash D, Lanning SP, Fox P, Martin JM, Blake NK, Souza E, Graybosch RA, Giroux MJ, Talbert LE (2006) Relationship of dough extensibility to dough strength in a spring wheat cross. Cereal Chem. https://doi.org/10.1094/CC-83-0255

32. Rehmana S, Patersonb A, Piggottb JR (2006) Chapatti quality from British wheat cultivar flours. Swiss Soc Food Sci Technol. https://doi.org/10.1016/j.Iwt.2006.04.009

Publisher's Note Springer Nature remains neutral with regard to jurisdictional claims in published maps and institutional affiliations. 